\title{
Chondroma of the hand with osteoid formation: first case report
}

This article was published in the following Dove Press journal:

International Medical Case Reports Journal

I2 July 20 I I

Number of times this article has been viewed

\section{Vincenzo Arena \\ Ilaria Pennacchia \\ Fabio Maria Vecchio \\ Arnaldo Carbone}

Institute of Pathology, Catholic University of Sacred Heart, Rome, Italy
Correspondence: Vincenzo Arena Institute of Pathology, Catholic University of Sacred Heart,

L. go F. Vito, Rome I00168, Italy

Tel $+390630 I 54270$

Fax +3906 305 II 57

Email vincenzo.arena@rm.unicatt.it
Abstract: Chondroma is the most common neoplasia of the hand. Histologically, it consists of lobules of normal-appearing hyaline cartilage showing a lobular arrangement. To the best of our knowledge, this is the first reported case of chondroma of the hand in which, interestingly, osteoid production was observed.

Keywords: chondroma, hand, osteoid

\section{Introduction}

It is well known that chondroma is the most common bone tumor of the hand. ${ }^{1,2}$ It originates from groups of proliferating chondrocytes of the physeal plate that, by a focal lack of chondrocyte hypertrophy, matrix calcification, and chondrocyte death as normally occurs in the process of endochondral ossification, are left behind and eventually isolated in the metaphysis. Macroscopically excised chondromas are usually well demarcated, have rounded or ovoid configurations, and are firm on palpation. Occasionally, chondromas are soft or friable with focal cystic change. Nearly all are small, rarely exceeding $3 \mathrm{~cm}$ in diameter. Histologically, the majority of them consist of mature or fairly hyaline cartilage arranged in a distinct lobular pattern. Frequently, the cartilage has focal or diffuse calcification and the calcified material is granular, floccular, or crystalline. In a typical chondroma, double-nucleated cells are rarely found and occasionally clusters of cells can be seen. When occurring in the bone of the hand, some worrisome features are expected (namely plump chondrocytes, pleomorphism), and a fair frequency of binucleated cells, with no indication of malignant behavior.

\section{Case report}

A 36-year-old woman came to our orthopedic unit with a swelling of the proximal phalanx on the third finger of the left hand that had appeared 5 months earlier. There was no history of previous trauma. Physical examination showed an enlargement of the affected finger. It was negative for pain, and hand function was preserved. The patient previously had an X-ray that showed the presence of an osteolytic lesion with a sclerotic rim suggesting a diagnosis of chondroma (radiograms not available). Magnetic resonance imaging showed the presence of an osteolytic lesion with polycyclic margins compatible with chondroma (Figure 1A). The lesion extended up to the ulnar cortex without evidence of pathologic fracture. Curettage of the lesion was performed. Grossly, the samples consisted of multiple fragments of white, opaque, and occasionally myxoid chondroid tissue. Histologically, the lesion was composed of a 


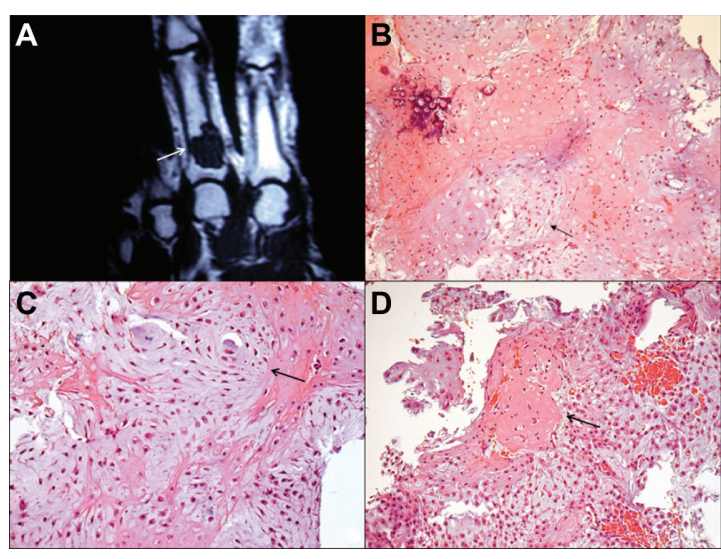

Figure I (A) Magnetic resonance image ( $\mathrm{TI}$-weighted) of the hand reveals a roughly oval, gently lobulated mass located in the proximal phalanx of the third finger (arrow). (B) Micrograph of a fragment obtained from curettage shows chondrocytic proliferation with a lobular pattern of growth and focal granular calcifications. The chondrocytes were normal without any morphologic sign of malignancy. (C) Micrograph of a myxoid area (arrow) with spindle-shaped cells in a basophilic matrix. (D) Under low power, areas of osteoid matrix deposition are visible focally within the lesion (arrow).

proliferation of well differentiated chondrocytes and mature hyaline cartilage arranged in a lobular manner. Areas of myxoid stroma with scattered cells having no atypical features were also present (Figure 1B). The nuclei were small, round, and relatively uniform in size. Neither double-nucleated cells nor clusters of chondrocytes were seen. In areas with a conspicuous myxoid component, cells appeared stellate and spindle-shaped (Figure 1C). No mitotic figures were seen and immunohistochemistry for MIB-1 showed a proportion of positive cells under $2 \%$. Interestingly, focal deposits of osteoid within the lesion were also seen (Figures 1D and 2). The patient suffered no relapse during 1 year of follow-up.

\section{Discussion}

The presence of focal myxoid areas in chondroma of the hand is reported in the literature. ${ }^{3,4}$ If the myxoid component is predominant, a myxoid variant of chondroma should be considered. In this context, the main differential diagnosis is myxoid chondrosarcoma. In our case, a diagnosis of malignancy was not considered due to the absence of cellular pleomorphism and because the hand is a very unusual site for malignant chondroid neoplasms. As for the unusual presence of osteoid matrix formation, it is described in both

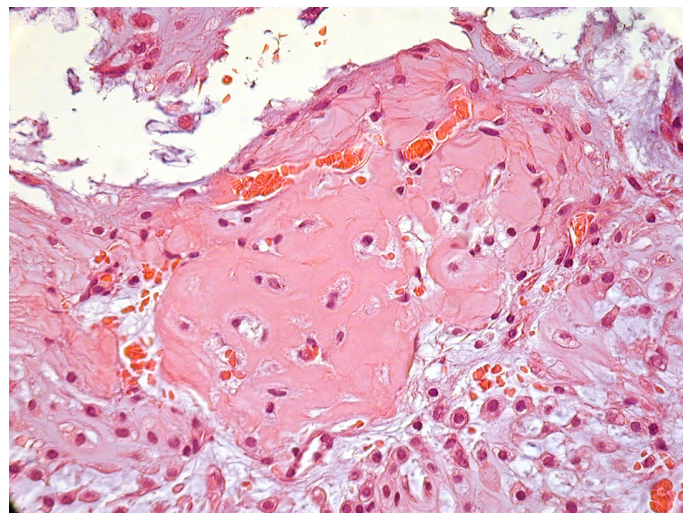

Figure 2 Osteoid matrix deposition.

chondroblastoma, in which areas showing osteoid-like matrix (in diffuse or trabecular pattern) are expected ${ }^{5}$ and in chondromyxoid fibroma. ${ }^{6}$ The lesion we described, even though it showed an osteoid formation, did not fulfill all the criteria for a diagnosis of the abovementioned entities. However, we believe the finding of an osteoid matrix is striking in the setting of a chondroma of the hand. It is common for both benign and malignant cartilage tumors to undergo pathologic fracture, making the histology of new bone formation associated with the cartilage somewhat complex, but in the case reported here, neither radiologic nor pathologic signs of fracture were seen. To the best of our knowledge, this is the first report in the literature of a chondroma of the hand with osteoid formation.

\section{Disclosure}

The authors report no conflicts of interest in this work.

\section{References}

1. Dahlin DC, Salvador AH. Cartilaginous tumors of the soft tissues of the hands and feet. Mayo Clin Proc. 1974;49:721-726.

2. Baumhoer D, Jundt G. Tumours of the hand: a review on histology of bone malignancies. J Hand Surg Eur Vol. 2010;35:354-361.

3. Fletcher C, Unni K, Mertens F. WHO classification of tumours. Pathology and genetics of tumours of soft tissue and bone. Lyon, France: IARC Press; 2002.

4. Weiss S, Goldblum J. Enzinger and Weiss's soft tissue tumors. London, UK: Elsevier; 2007.

5. Aigner T, Loos S, Inwards C, et al. Chondroblastoma is an osteoid-forming, but not cartilage-forming neoplasm. J Pathol. 1999;189:463-469.

6. Mirra JM. Bone tumors. Philadelphia, PA: Lea and Febiger; 1989.
International Medical Case Reports Journal

\section{Publish your work in this journal}

The International Medical Case Reports Journal is an international, peer-reviewed open-access journal publishing original case reports from all medical specialties. Previously unpublished medical posters are also accepted relating to any area of clinical or preclinical science. Submissions should not normally exceed 2,000 words or

\section{Dovepress}

4 published pages including figures, diagrams and references. The manuscript management system is completely online and includes a very quick and fair peer-review system, which is all easy to use. Visit http://www.dovepress.com/testimonials.php to read real quotes from published authors. 